\title{
Topic liver hypothermia and ischemic preconditioning. A new model of ischemia and reperfusion in rats ${ }^{1}$
}

\author{
Hipotermia hepática tópica e pré-condicionamento isquêmico. Um novo modelo de isquemia e \\ reperfusão em ratos
}

\author{
Tomaz de Jesus Maria Grezzana Filho', Tais Burmann de Mendonça ${ }^{\mathrm{II}}$, Gémerson Gabiatti' ${ }^{\mathrm{II}}$, Cleber Dario Pinto Kruel ${ }^{\mathrm{IV}}$, \\ Carlos Otávio Corso ${ }^{\mathrm{V}}$ \\ ${ }^{\text {I }}$ Fellow PhD degree, Department of Surgery, UFRGS, Brazil. \\ ${ }^{\text {II }}$ Graduate Student, Faculty of Medicine, UFRGS, Brazil. \\ III Master, General Surgeon. \\ ${ }^{\text {IV }} \mathrm{PhD}$, Associate Professor, Department of Surgery, Post-graduate Program of Surgical Sciences, UFRGS, Brazil. \\ ${ }^{v} \mathrm{PhD}$, Associate Professor, Department of Morphologic Sciences, Post-graduate Program of Surgical Sciences, UFRGS, Brazil.
}

\begin{abstract}
Purpose: Evaluation of the Mean Arterial Pressure (MAP) and body temperature changes in a new model of liver ischemia-reperfusion applying topical Hypothermia and Ischemic Preconditioning (IPC). Methods: Rats $(\mathrm{n}=32)$ were divided in 5 groups: Control (C), Normothermic Ischemia (NI), Ischemic Preconditioning (IPC), Hypothermia $26^{\circ} \mathrm{C}$ plus IPC (H+IPC) and Hypothermia $26^{\circ} \mathrm{C}(\mathrm{H})$. MAP and body temperature were recorded at 30 minutes intervals throughout the entire experiment. The study groups underwent 90 minutes partial hepatic ischemia followed by 120 minutes of reperfusion. The median and lateral left lobes were isolated and topical $26^{\circ} \mathrm{C}$ hypothermia was induced by superfusion of cooled saline solution in H+IPC and $\mathrm{H}$ groups. A 10 minutes protocol of ischemia and reperfusion was applied in the IPC and H+IPC groups before the major ischemic insult. Results: There was no significant difference in MAP and body temperature means between the groups throughout the experiments. Conclusion: The present model allows the induction of topical hepatic hypothermia associated or not to IPC. New studies to evaluate the possible synergistic effects of these tools can be reproduced without significant changes in macrohemodynamics and body temperature, or in other words, under stable conditions Key words: Hypothermia, Induced. Ischemic Preconditioning. Rats.
\end{abstract}

\section{RESUMO}

Objetivo: Avaliar as variações de temperatura corporal, pressão arterial média (PAM) em um novo modelo de isquemia e reperfusão hepático que utiliza Pré-condicionamento isquêmico e Hipotermia tópica. Métodos: Ratos $(\mathrm{n}=32)$ da raça Wistar foram divididos em 5 grupos: Controle (C), Isquemia normotérmica (IN), Hipotermia a $26^{\circ} \mathrm{C}(\mathrm{H})$, Pré-condicionamento isquêmico (PCI) e Hipotermia a $26^{\circ} \mathrm{C}$ com Pré-condicionamento isquêmico com hipotermia (H+PCI). As aferições da PAM e temperatura corporal foram realizadas em intervalos de 30 minutos. Os animais foram submetidos à isquemia hepática de 90 minutos e 120 minutos de reperfusão. Nos grupos H e H+PCI, o fígado foi isolado e resfriado por superfusão de solução fisiológica gelada. Nos grupos com PCI e H+PCI foram aplicados 10 minutos de isquemia e 10 minutos de reperfusão antes do insulto isquêmico maior. Resultados: Não houve diferença na PAM e temperatura corporal entre os grupos durante todo o experimento. Conclusão: O presente modelo permite a aplicação de hipotermia local associada ou não ao PCI. Novos estudos para avaliar os possíveis efeitos sinergísticos destas ferramentas podem ser reproduzidos sem alterações significativas na macrohemodinâmica e temperatura corporal, ou seja, sob condições estáveis.

Descritores: Hipotermia Induzida. Precondicionamento isquêmico. Ratos.

${ }^{1}$ Research performed at the Animal Experimentation Unit, Clinics Hospital of Porto Alegre, Federal University of Rio Grande do Sul (UFRGS), Brazil.

\section{Introduction}

During major liver resections, blood flow to the liver can be temporarily occluded to prevent massive blood loss. Evidences shows that normal livers tolerate 60 minutes of ischemia without sustaining significant injuries ${ }^{1,2,3}$. However, complex resections demand extended periods of ischemia which can compromise the organ viability in the post-operative period. In addition, resections in livers with chronic diseases and steatosis are related to less tolerance to hypoxia and elevated rates of dysfunction ${ }^{3,4}$.

In order to attenuate the ischemia-reperfusion injuries and perform complex liver resections, some authors recommend the use of protective tools, such as Hypothermia and IPC. These techniques have been related to the reduction of oxidative stress, less ATP consumption and microcirculation protection ${ }^{3,5}$. The Hypothermia in liver surgery can be induced by total body cooling, 
hypothermic perfusion cooling, extracorporeal cooling or topical (surface) cooling ${ }^{6,7,8}$. On the other hand, IPC is an inducible and potent endogenous mechanism by which repeated episodes of brief Ischemia and Reperfusion (I/R) lead to a state of protection against subsequent sustained I/R injury. Due to simplicity and easy execution, the IPC has been evaluated in many experimental and clinical situations $\mathrm{s}^{9,10,11,12}$.

In theory, the use of both techniques in liver surgery could offer synergistic effects, but until now there is no information available about the changes of homodynamic parameters or body temperature when these tools are associated. In this work, we used a model of moderate topical cooling previously developed ${ }^{6,13}$ plus IPC, aiming to observe the changes in MAP and body temperature.

\section{Methods}

This study was approved by the Bioethical Committee for Animal Experimentation at Post-Graduation Group at HCPA-UFRGS which follows the Council for International Organization of Medical Sciences (CIOMS) ethical code for animal experimentation. Male Wistar rats weighting 200-250g were housed under standard environmental conditions with a 12-hour light/dark cycle. The animals fasted overnight with unlimited access to water before their use in the experiments.

\section{Experimental design}

\section{Control Group (C)}

Animals underwent laparotomy and all preparation remaining without hepatic ischemia during the entire experiment, $(n=4)$.

\section{Normothermic Ischemia (NI)}

Livers were subjected to ischemia of the median and left lateral lobes for 90 minutes and subsequent reperfusion for 120 minutes, $(n=7)$.

\section{Ischemic Preconditioning (IPC)}

Ischemic preconditioning consisted of 10 minutes of warm ischemia and 10 minutes of reperfusion. Thereafter, the preconditioned liver lobes were exposed to 90 minutes of ischemia followed by 120 minutes of reperfusion, $(n=7)$.

\section{Hypothermia $(\mathrm{H})$}

Immediately after the ischemia had begun, the median and left lateral liver lobes were cooled to $26^{\circ} \mathrm{C}$ for 90 minutes. Thereafter, the livers were reperfused for 120 minutes in normothermia, $(n=7)$.

\section{Hypothermia plus Ischemic Preconditioning (H+IPC)}

Ischemic preconditioning consisted of 10 minutes of warm ischemia and 10 minutes of reperfusion. Immediately after the ischemia had begun, the median and left lateral liver lobes were cooled to $26^{\circ} \mathrm{C}$ for 90 minutes. Thereafter, the livers were reperfused for 120 minutes in normothermia, $(n=7)$.

\section{Surgical procedures}

Animals were anesthetized with ketamin sulfate $75 \mathrm{mg} / \mathrm{kg}$ and Xylazin $10 \mathrm{mg} / \mathrm{kg}$ ip. One-third supplements of the initial dose were administrated according to the first signs of anesthetic recovery. Animals were placed in supine position on a heated pad and the rectal temperature was measured in 30 minutes intervals using a digital thermometer and immediately adjusted when necessary with a heating lamp to reach a temperature between $35.5^{\circ} \mathrm{C}-37.5^{\circ} \mathrm{C}$. A polypropylene catheter (PE-50) was inserted into the right carotid for recording of MAP in 30 minutes intervals and continuous volume replacement with normal saline $0.9 \%(2 \mathrm{ml} / \mathrm{h})$. Oxygen (11/min) was administrated using a face mask.

The liver was exposed through a transverse bilateral incision and retractors were positioned in the rib cage. The liver was released from its ligaments and the branches of the portal vein and hepatic artery supplying the left and median liver lobes were identified and clamped for 90 minutes using an atraumatic microvascular clip. The un-occluded right and caudate lobes allowed outflow from the splanchnic circulation, thus avoiding venous congestion. For the duration of hepatic ischemia, the abdominal cavity remained opened. The top of the surgical table was elevated 30 degrees and the median and lateral liver lobes mobilized carefully into a polyethylene concave device as described previously ${ }^{13}$. A flexible intraparenchymal probe (IT-23, diameter $0.5 \mathrm{~mm}$ ) connected to a digital thermometer was introduced into the left lateral lobe and the temperature adjusted to $26^{\circ} \mathrm{C}$ by cooled saline superfusion in the $\mathrm{H}$ and $\mathrm{H}+\mathrm{IPC}$ groups (Figure 1).

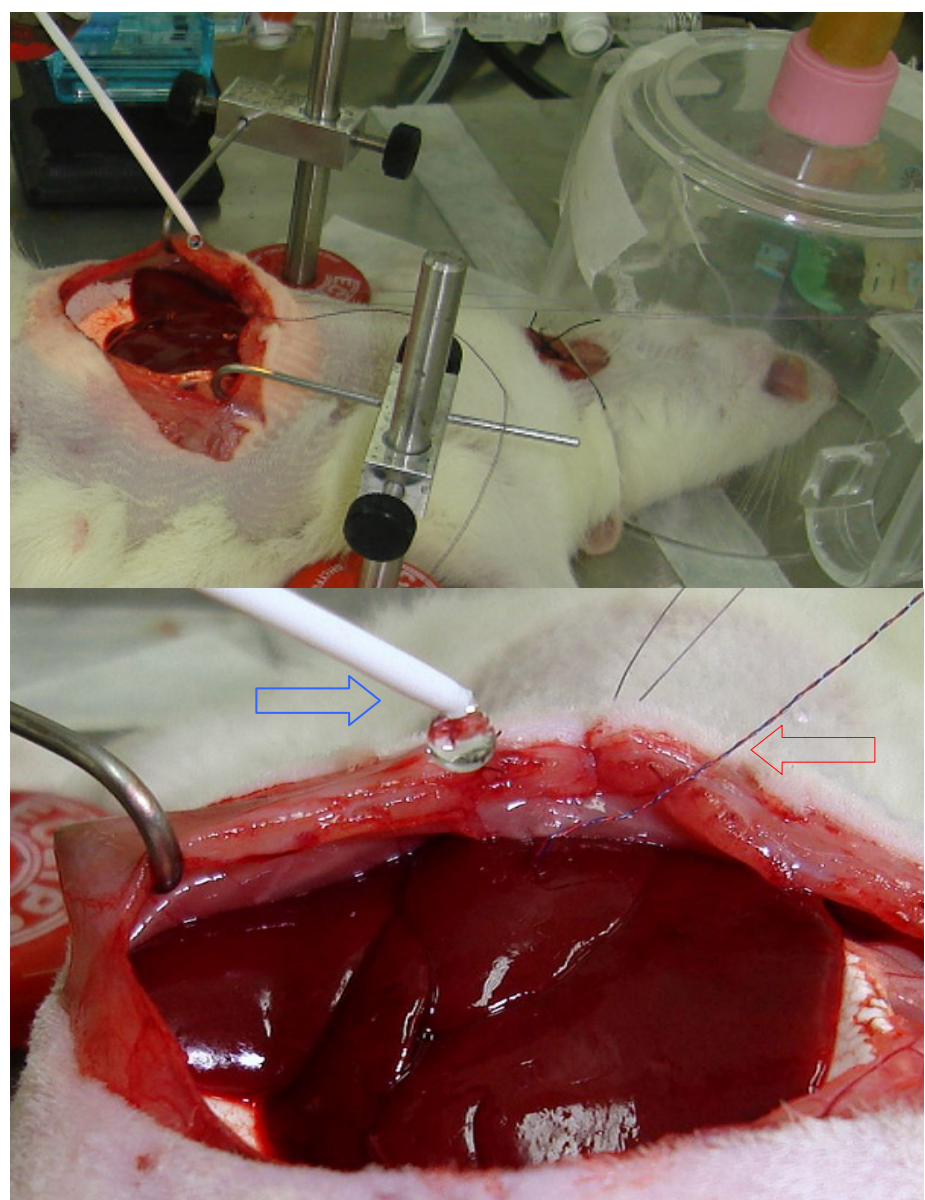

FIGURE 1 - Liver mobilized into a specially designed polyethylene device. Blue arrow: Superfusion of cold saline. Red arrow: Flexible probe introduced into liver parenchyma 
To avoid spillover of the cooled saline into the abdominal cavity and consecutive systemic cooling of the animal, a suction system was installed to remove fluid. IPC consisted of 10 minutes of warm ischemia and 10 minutes of reperfusion before the prolonged ischemia only in the IPC and IPC $+\mathrm{H}$ groups. After 90 minutes of ischemia, the clip was removed and the liver reperfused for 120 minutes. At the end of the experiment animals were sacrificed.

\section{Statistical analysis}

All data are presented as Means \pm SEM. Comparisons of MAP and temperature data between study groups were performed by one-way ANOVA, using the Dunnet two-sided post hoc test. $\mathrm{P}$ values $<0.05$ were considered as statistically significant.

\section{Results}

\section{Temperature}

\section{$\underline{\text { Ischemia }}$}

During the 90 minutes of ischemia, body temperature means ranged from $36.5 \pm 0.1^{\circ} \mathrm{C}-36.9 \pm 0.3{ }^{\circ} \mathrm{C}$ in the $\mathrm{C}$ group, $36.5 \pm 0.2{ }^{\circ} \mathrm{C}-37.0 \pm 0.2{ }^{\circ} \mathrm{C}$ in the IN group, $36.5 \pm 0.1{ }^{\circ} \mathrm{C}-36.9 \pm$ $0.3{ }^{\circ} \mathrm{C}$ in the IPC group, $37.0 \pm 0.1^{\circ} \mathrm{C}-37.4 \pm 0.1$ in the $\mathrm{H}+\mathrm{IPC}$ groups and $35.8 \pm 0.5^{\circ} \mathrm{C}-36.5 \pm 0.4^{\circ} \mathrm{C}$ in the $\mathrm{H}$ group. No differences were seen in any of the evaluated body temperature means when the groups were compared (Figure 2).

em perature Means

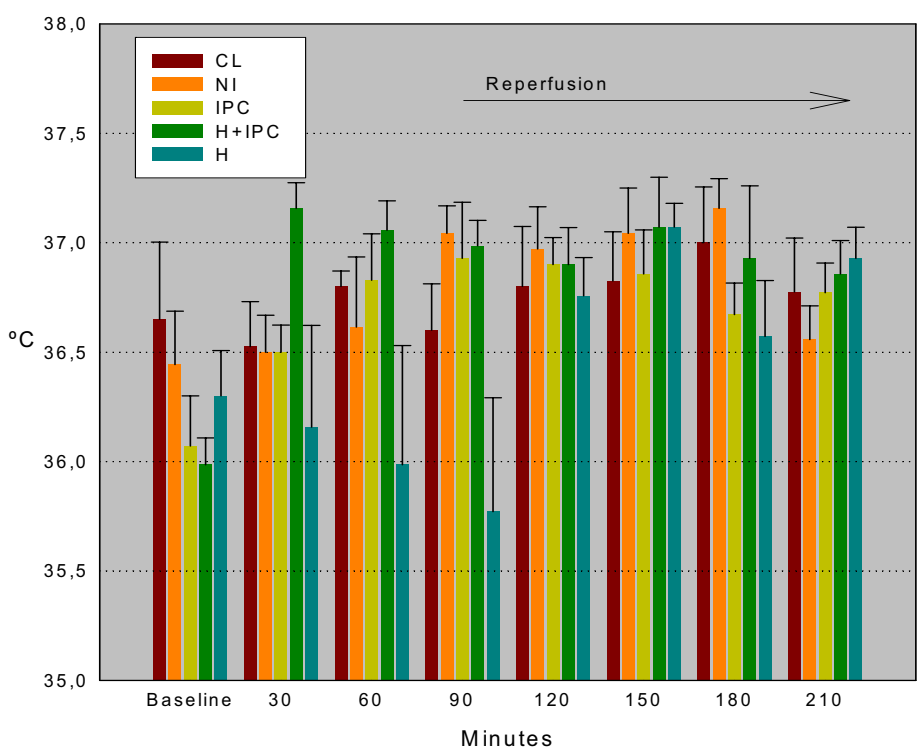

FIGURE 2 - Temperature means of each evaluation in all groups. Ischemia: 30-90 minutes. Reperfusion: 120-210 minutes. No significant differences between the groups

\section{$\underline{\text { Reperfusion }}$}

After the reperfusion, the body temperature means ranged from $36.5 \pm 0.3{ }^{\circ} \mathrm{C}-37.0 \pm 0.3{ }^{\circ} \mathrm{C}$ in the $\mathrm{C}$ group, $36.6 \pm 0.2{ }^{\circ} \mathrm{C}-$ $37.2 \pm 0.1^{\circ} \mathrm{C}$ in the IN group, $36.5 \pm 0.1^{\circ} \mathrm{C}-37.1 \pm 0.2^{\circ} \mathrm{C}$ in the IPC group, $36.9 \pm 0.2{ }^{\circ} \mathrm{C}-37.2 \pm 0.2{ }^{\circ} \mathrm{C}$ in the $\mathrm{H}+\mathrm{IPC}$ group and $36.5 \pm 0.4{ }^{\circ} \mathrm{C}-37.1 \pm 0.2{ }^{\circ} \mathrm{C}$ in the $\mathrm{H}$ group.

Similarly to the ischemia period, after the reperfusion the means of body temperatures demonstrated no significant differences between the groups in any of the evaluations (Figure 2).

\section{$M A P$}

\section{$\underline{\text { Ischemia }}$}

During 90 minutes of ischemia, MAP means ranged from $76.5 \pm 3.1 \mathrm{mmHg}-83.5 \pm 3.1 \mathrm{mmHg}$ in the $\mathrm{C}$ group, $86.3 \pm 3.8$ $\mathrm{mmHg}-101.0 \pm 5.8 \mathrm{mmHg}$ in the IN group, $90.7 \pm 5.4 \mathrm{mmHg}-$ $97.9 \pm 6.1 \mathrm{mmHg}$ in the IPC group, $84.7 \pm 3.8 \mathrm{mmHg}-90.6 \pm 4.3$ $\mathrm{mmHg}$ in the H+IPC group and $88.0 \pm 5.6 \mathrm{mmHg}-96.0 \pm 4.6$ $\mathrm{mmHg}$ in the $\mathrm{H}$ group. No differences were seen in MAP means in any of the evaluation when the groups were compared (Figure 3).

\section{$\underline{\text { Reperfusion }}$}

After the reperfusion MAP means ranged from $83.8 \pm$ $1.8 \mathrm{mmHg}-88.8 \pm 7.4 \mathrm{mmHg}$ in the $\mathrm{C}$ group, $83.3 \pm 4.5 \mathrm{mmHg}$ $-94.3 \pm 4.9 \mathrm{mmHg}$ in the IN group, $86.3 \pm 3.2 \mathrm{mmHg}-96.9 \pm$ $4.7 \mathrm{mmHg}$ in the IPC group, $82.6 \pm 4.4 \mathrm{mmHg}-94.7 \pm 4.2 \mathrm{mmHg}$ in the H+IPC group and $84.7 \pm 5.0 \mathrm{mmHg}-97.3 \pm 6.7 \mathrm{mmHg}$ in the $\mathrm{H}$ group. However, no differences in MAP means were seen between the groups in any of the evaluations (Figure 3 ).

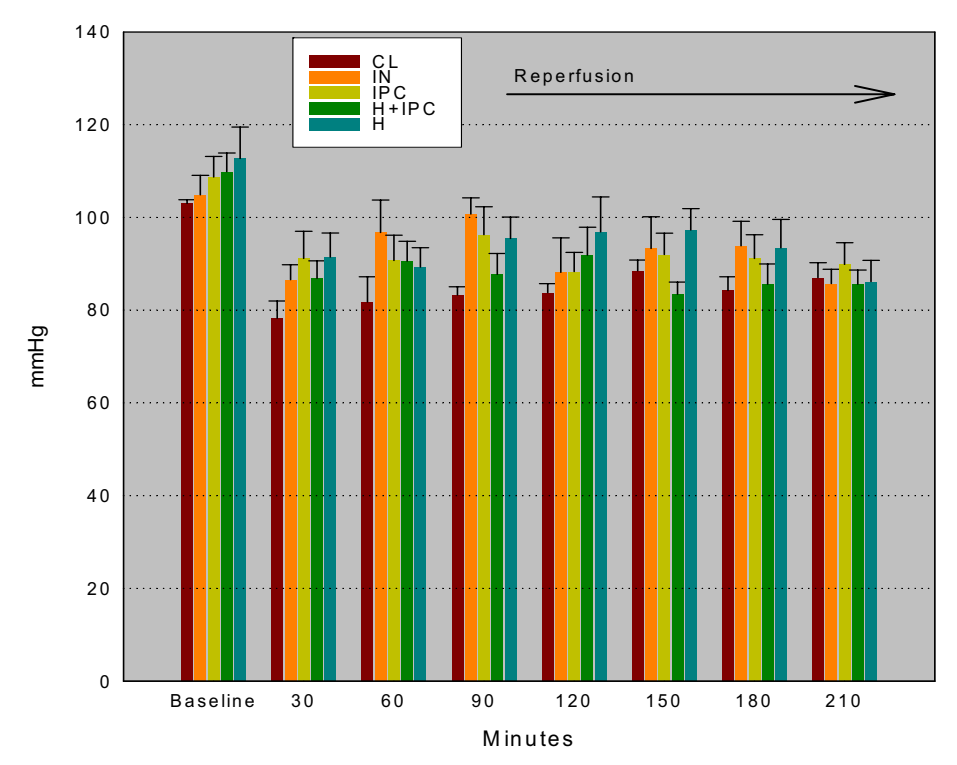

FIGURE 3 - MAP means of each evaluation in all groups. Ischemia: 30-90 minutes. Reperfusion: 120-210 minutes. No significant differences between the groups 


\section{Discussion}

The present model of ischemia associates two potentially protective tools against liver injuries involved in $\mathrm{I} / \mathrm{R}$, emphasizing the hemodynamic variations and body temperature at the initial phase of reperfusion. To our knowledge, this is the first report of the simultaneous use of Hypothermia and IPC in the liver, whereas this combination was already reported in brain and heart surgery ${ }^{14,15}$.

In the present study, there was a mild increase in temperatures at the start of the experiment in all groups, an effect probably related to the artificial warming, since during anesthesia there is always an impairment of thermoregulation and decreased vasoconstriction with redistribution of the heat from the core to periphery and consequent body hypothermia. During the ischemia, there was a tendency to decrease in temperature means only in the $\mathrm{H}$ group, an effect of the superfusion of cooled saline on the liver.

At the start of the experiment, there was a decrease in MAP means in all groups. This finding probably is related to the anesthetic drugs, since controls were not submitted to ischemia and also presented this behavior. At the start of the hepatic ischemia, MAP means showed partial recovery in all groups, an effect related to the compensatory increase of cardiac output and peripheral vasoconstriction promoted by portal clamping. There were not negative reflexes associated with the induction of hypothermia in MAP means and there was no difference in MAP means between the groups in any of the evaluations.

Immediately after the reperfusion, all groups presented a significant decrease in MAP means, a finding related to heart depression and the release of mediators which follows the restoration of blood flow to the liver. Thereafter, a spontaneous recovery was seen in the next MAP measurement.

The findings showed that the induction of topical $26^{\circ} \mathrm{C}$ liver hypothermia associated or not to IPC in rats had no significant influence on body temperature and MAP during 90 minutes of ischemia and 120 minutes of reperfusion, a model associated with severe liver injuries ${ }^{16}$. In addition, this model has proved to be easily reproducible, with low mortality, despite long duration of ischemia.

Up until now there is no consensus about the best level of temperature which should be applied, but a set of evidences points that a mild or moderate hypothermia is able to confer protection to the liver ${ }^{4,17,18}$. The main mechanism of protection postulated is a decrease of cellular metabolism and oxygen requirement, which occurs consequent to hypothermia, preserving energy and allowing a longer period of inflow occlusion ${ }^{5,17,19}$. However, the IPC also has been related to a lesser demand of energy and this is one of the mechanisms attributed to the liver protection ${ }^{20}$. Since this model of $70 \%$ ischemia avoids the splanchnic congestion, the role of intestinal mediators can be less significant than mediators released by Kuppfer cells.

Even with the strong evidence of benefits in the liver and other target-organs ${ }^{21}$, the use of body hypothermia has been limited because the risks of inducing hemodynamic disturbances, coagulopathy, metabolic acidosis and arrhythmias ${ }^{19}$. In addition, the technique of in situ liver perfusion is complex, demanding total vascular exclusion and veno-venous by-pass ${ }^{7,22,23}$. Some authors have reported that situ hypothermic perfusion did not demonstrate better effects compared to topical cooling ${ }^{24}$. Thus, topical cooling has emerged as an alternative less invasive, time-saving and cost efficient as an adjunct to complex liver resections ${ }^{6,8,25}$.
According to our findings, the influence in body temperature and MAP is minimal when a moderate topical hypothermia at $26^{\circ} \mathrm{C}$ is applied for 90 minutes. In line with these findings, other authors have related that topical cooling can safely prolong the hepatic inflow occlusion from 60 to 90 minutes, even in the presence of chronic liver disease without significant hemodynamic imbalance and body temperature decrease ${ }^{25}$.

\section{Conclusion}

This new model allows the investigation of the influence of topical hypothermia at $26^{\circ} \mathrm{C}$ associated or not to IPC, being stable and reliable. It can be further used for systematic investigation of the ideal temperature of the liver during ischemia and the mechanisms involved in liver protection without interference in body temperature and macrohemodynamics.

\section{References}

1. Hannoun L, Borie D, Delva E, Jones D, Vaillant JC, Nordlinger B, Parc $\mathrm{R}$. Liver resection with normothermic ischaemia exceeding one hour. Br J Surg. 1993;80:1161-5.

2. Huguet C, Addario-Chieco P, Gavelli A, Arrigo E, Harb J, Clement RR.Technique of hepatic vascular exclusion for extensive liver resection. Am J Surg. 1992;163:602-5.

3. Kim Y. Ischemia-reperfusion injury of the human liver during hepatic resection. Hepatobiliary Pancreat Surg. 2003;10:195-9.

4. Niemann CU, Choi S, Behrends M, Hirose R, Coatney JL, Roberts JP, Serkova NJ, Maher JJ. Mild hypothermia protects obese rats from fulminant hepatic necrosis induced by ischemia-reperfusion. Surgery. 2006;140:404-12.

5. Yamanaka N, Furukawa K, Tanaka T, Tanaka W, Yamanaka J, Imakita M, Okamoto E. Topical cooling-assisted hepatic segmentectomy for cirrhotic liver with hepatocellular carcinoma. J Am Coll Surg. 1997;184:290-6.

6. Khandoga A, Enders G, Luchting B, Axmann S, Minor T, Nilsson U, Biberthaler P, Krombach F. Impact of intraischemic temperature on oxidative stress during hepatic reperfusion. Free Rad Biol Med. 2003;35:901-9.

7. Heijnen BHM, Straatsburg IH, Gouma DJ, van Gulik TM. Decrease in core liver temperature with $10^{\circ} \mathrm{C}$ by in situ hypothermic perfusion under total hepatic vascular exclusion reduces liver ischemia and reperfusion injury during partial hepatectomy in pigs. Surgery. 2003;134:806-17.

8. Yamanaka N, Daí CL, Okamoto E. Historical evolution of hypothermic liver surgery. World J Surg. 1998;22:1104-7.

9. Koti RS, Seifalian M, McBride AG, Yang W, Davidson BR. The relationship of hepatic tissue oxygenation with nitric oxide metabolism in ischemic preconditioning of the liver. FASEB J. 2002;16:1654-6.

10. Heizmann O, Loehe F, Volk A, Schauer RJ. Ischemic preconditioning improves postoperative outcome after liver resections: a randomized controlled study. Eur J Med Res. 2008;25:79-86.

11. Petrowski H, McCormack L, Trujillo M, Selzner M, Jochum W, Clavien PA. A prospective controlled trial comparing intermittent portal triad clamping versus ischemic preconditioning with continuous clamping for major liver resection. Ann Surg. 2006;244:921-8.

12. Serafin A, Rosselló-Catafau J, Prats N, Xaus C, Gelpi E, Peralta C. Ischemic preconditioning increases the tolerance of fatty liver to hepatic ischemia-reperfusion injury in the rat. Am J Pathol. 2002;161:587-601.

14. Lee YJ, Miyake S, Wakita H, McMullen DC, Azuma Y, Auh S, Hallenbeck JM. Protein SUMOylation is massively increased in hibernation torpor and is critical for the cytoprotection provided by ischemic preconditioning and hypothermia in SHSY5Y cells. J Cereb Blood Flow Metab. 2007;27:950-62. 
15. An J, Camara AK, Rhodes SS, Riess Ml, Stowe DF. Warm ischemic preconditioning improves mitochondrial redox balance during and after mild hypothermic ischemia in guinea isolated hearts. Am J Physiol Heart Circ Physiol. 2005;288:2620-7.

16. Jaeschke H. Molecular mechanisms of hepatic ischemia/reperfusion injury and preconditioning. Am J Physiol Gastrointest Liver Physiol. 2003;284:G15-26.

17. Behrends M, Hirose R, Serkova NJ, Coatney JL, Yardi J, Niemann CU. Mild hypothermia reduces the inflammatory response and hepatic ischemia/reperfusion injury in rats. Liver Int. 2006;26:734-41.

18. Vaquero J, Bélanger M, James L, Herrero R, Desjardins P, Côté J, Blei AT, Butterworth RF. Mild hypothermia attenuates liver injury and improves survival in mice with acetaminophen toxicity. Gastroenterology. 2007;132:372-83.

19. Vejchapitat P, Poomsawat S, Poovorawan Y, Proctor E, Pierro A. The effects of moderate hypothermia on energy metabolism and serum inflammatory markers during laparotomy. Pediatr Surg Int. 2006;22:66-71. 20. Selzner N, Selzner M, Jochum W, Clavien PA. Ischemic preconditioning protects the steatotic mouse liver against reperfusion injury: an ATP dependent mechanism. J Hepatol. 2003;39:55-61.
21. Patel S, Pachter HL, Yee H, Schwartz JD, Marcus SG, Shamamian P. Topical hepatic hypothermia attenuates pulmonary injury after hepatic ischemia and reperfusion. J Am Coll Surg. 2000;191:650-6.

22. Azoulay D, Eshkenazy R, Andreani P, Castaing D, Adam R, Ichai P, Naili S, Vinet E, Saliba F, Lemoine A, Gillon MC, Bismuth H. In situ hypothermic perfusion of the liver versus standard total vascular exclusion for complex liver resection. Ann Surg. 2005;241:277-85.

23. Dinant S, van Veen SQ, Roseboom HJ, van Vliet AK, van Gulik TM. Liver protection by hypothermic perfusion at different temperatures during total vascular exclusion. Liver Int. 2006;26:486-93.

24. Ohya T, Ohwada S, Morishita Y. Does hypothermic perfusion have beneficial effects for ischemic liver during extended hepatectomy with hepatic inflow occlusion of canine liver? A comparative study with topical cooling. Hepatogastroenterology. 1998;45:477-82.

25. Biberthaler P, Luchting B, Massberg S, Teupser D, Langer S, Leiderer $\mathrm{R}$, Messmer K, Krombach F. The influence of organ temperature on hepatic ischemia-reperfusion injury. Transplantation. 2001;72:1486-90.

\section{Correspondence:}

Conflict of interest: none Financial source: $\mathrm{CNPq}$ and

Tomaz de Jesus Maria Grezzana Filho

Rua Irmão José Otão, 170/406

90035-060 Porto Alegre - RS Brazil

Phone: (55 51)3209-0848

tomgrez@uol.com.br

Received: January 13, 2009

Review: March 11, 2009

Accepted: April 14, 2009

\section{How to cite this article}

Grezzana Filho TJM, Mendonça TB, Gabiatti G, Kruel CDP, Corso CO. Topic liver hypothermia and ischemic preconditioning. A new model of ischemia and reperfusion in rats. Acta Cir Bras. [serial on the Internet] 2009 July-Aug;24(4).

Available from URL: http://www.scielo.br/acb 